\title{
ORBITAL TUBERCULOSIS DIAGNOSED BY IMMUNOHISTOCHEMISTRY: CASE REPORTS
}

\author{
Bráulio F.T. OLIVEIRA(1), Fernanda C. TAKAY(1), Tatiana M. SHIDA(1), Ruth M. SANTO(1), Abelardo C. SOUZA Jr.(2) \& Suzana MATAYOSHI(1)
}

\begin{abstract}
SUMMARY
Purpose: To describe three cases of orbital tuberculosis, with their clinical characteristics and respective diagnostic procedures, showing the importance of histopathology for the correct diagnosis.

Patients and Methods: Three patients diagnosed and treated for orbital tuberculosis, in the "Hospital das Clínicas da Faculdade de Medicina da Universidade de São Paulo" during the years of 1999 and 2001.

Results: All of the patients were female and referred a chronic evolution of swelling of one eyelid associated or not with other symptoms. They had not HIV infection. Two of them had positive epidemiology for tuberculosis. However, the search for systemic evidence of the disease and staining for bacilli (Ziehl-Neelsen method) were negative in all three patients. In all the cases, only the biopsy with immunohistochemical analysis could confirm the diagnosis.

Comments: Orbital involvement is a rare ocular manifestation of tuberculosis. Even in a tertiary hospital, few cases, if any, are diagnosed per year. However, the global incidence and prevalence of $M$. tuberculosis infections is not under control yet, and it has been a serious public health problem. Thus, one must be aware of the possibility of tuberculosis among the orbital diseases.
\end{abstract}

KEYWORDS: Tuberculosis; Orbit; Diagnosis; Immunochemistry.

\section{INTRODUCTION}

Orbital involvement is a rare ocular manifestation of tuberculosis. Even in a tertiary hospital, few cases, if any, are diagnosed per year. However, the global incidence and prevalence of M. tuberculosis infections is not under control yet, and it has been a serious public health problem. Thus, one must be aware of the possibility of tuberculosis among the orbital diseases. This study describes three cases of orbital tuberculosis, with their clinical characteristics and the respective diagnostic procedures, showing the role of immunochemistry for the correct diagnosis.

\section{PATIENTS AND METHODS}

We carried out a retrospective study on three patients diagnosed and treated for orbital tuberculosis, in the "Hospital das Clínicas da Faculdade de Medicina da Universidade de São Paulo", Brazil, during the years of 1999 and 2001.

Case 1: A 52-year-old black woman presented with a one-month history of a tumor growing in her left lid. She did not have fever or respiratory symptoms, nor epidemiology for HIV.
The eye examination revealed an endured, cold and painless swelling of the left upper eyelid associated with proptosis, without restriction of the eye movements (Fig.1A). Visual acuity was 20/20, and the fundus had no alterations.

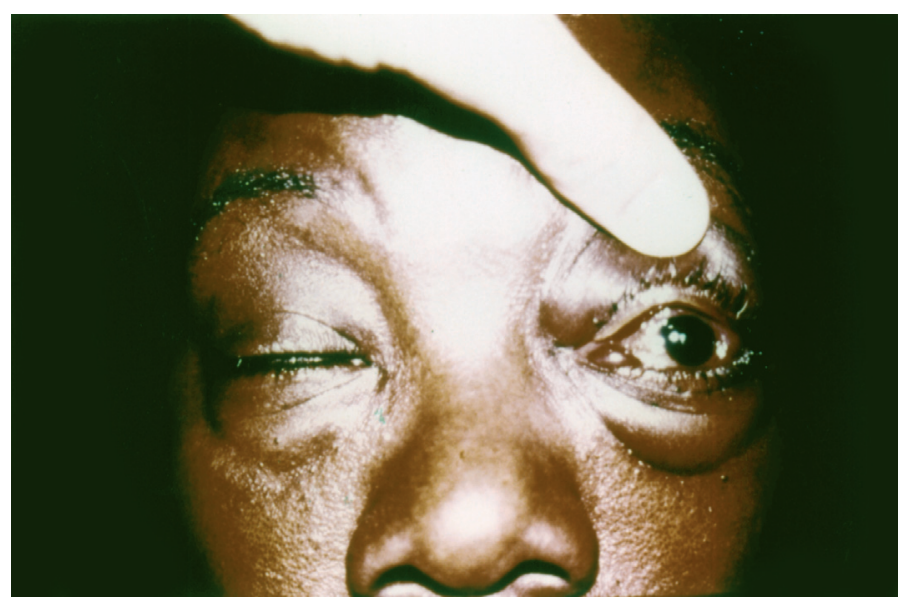

Fig. 1A - Case 1: First diagnosed as left orbital pseudotumor 
The chest X-Ray was normal, and sputum examination was negative for acid-fast bacilli. A computed tomography of the orbits revealed pre and post-septal involvement of soft tissues, including orbital fat (Fig.1B).

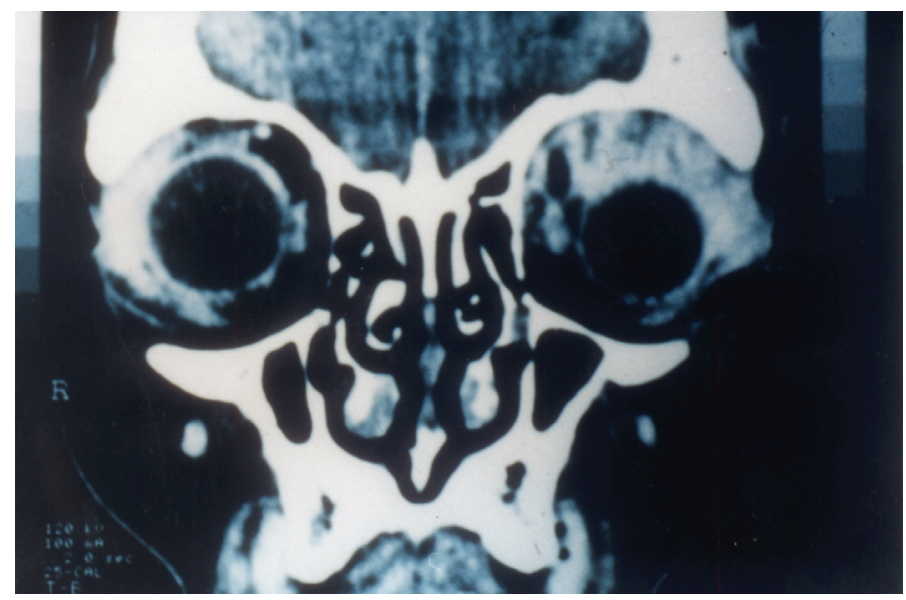

Fig. 1B - Case 1: Cat scan- inespecif left orbital mass

Based on the clinical, laboratory and radiological findings, a therapy for pseudotumor of the orbit was started (systemic corticosteroids). Initially, there was partial improvement of the symptoms; however, we noticed worsening with attempts to diminish medication, which was used for approximately 45 days and then stopped.

One month after interrupting medication, the condition recurred more intensely, with augmenting proptosis, chemosis and restriction of eye movements. At this stage, an incisional biopsy was performed.

A granulomatous process was observed in the histopathological examination of the tissue. Although the staining for acid-fast bacilli (Ziehl-Neelsen method) was negative, immunohistochemical study revealed $M$. tuberculosis inside giant-cells.

When the patient was told to have tuberculosis, she referred to having a relative with the active disease, and without any treatment.

After appropriate treatment for tuberculosis (rifampin $600 \mathrm{mg}$ daily, isoniazid $400 \mathrm{mg}$ daily and pyrazinamide $2 \mathrm{~g}$ daily), there was progressive improvement of the symptoms, and as there was a residual mass after six months of treatment, it was extended for three months more.

Case 2: A 58-year-old black woman sought for medical attention due to an eyelid tumor, which she had noticed one year before. She had also been having cough for four months and night fever for three months, and there had been a history of treatment for pulmonary tuberculosis 12 years ago. She did not have epidemiology for HIV infection.

The examination revealed diffuse swelling of the right upper eyelid, mainly in the temporal side, which was endured, painless, without any inflammation; there was no impairment of ocular motility. Biomicroscopy and fundoscopy were unremarkable (Fig. 2) .

The chest X-ray was normal, search for acid-fast bacilli in sputum was negative and computed tomography of the orbits revealed a non-

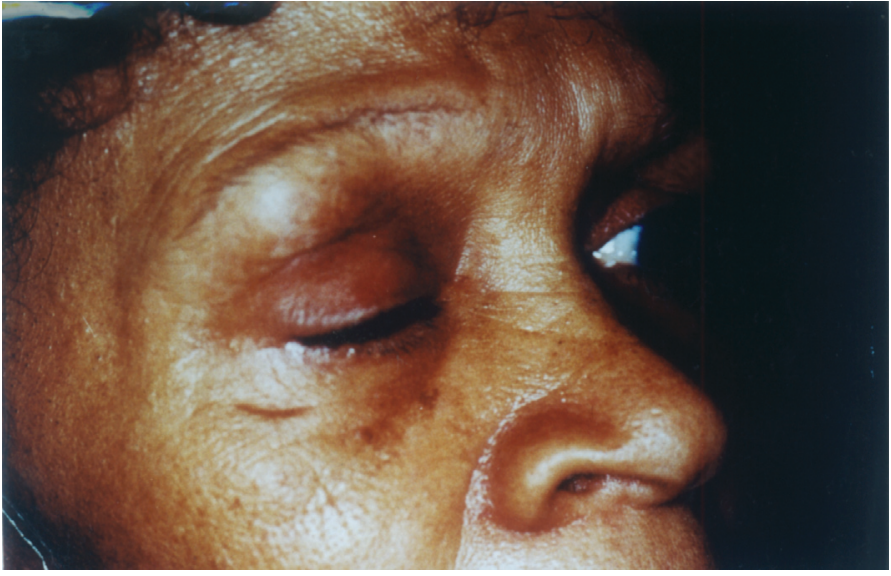

Fig. 2 - Case 2: Diffuse swelling of the right upper eyelid, mainly in the temporal part.

specific involvement of soft tissue. Further in the investigation, a biopsy indicated a granulomatous process, with negative staining for acid-fast bacilli, but a positive immunohistochemical test for M. tuberculosis.

After starting specific therapy for tuberculosis (rifampin $600 \mathrm{mg}$ daily, isoniazid $400 \mathrm{mg}$ daily and pyrazinamide $2 \mathrm{~g}$ daily, for six months), the symptoms remitted completely.

Case 3: A 3-year-old white girl was taken to the hospital due to conjunctival redness and left lower lid swelling for three months. Her mother described spontaneous remissions and recurrences for three times, and told that since one month the condition had been constantly present. Her general health was good, and she was using antibiotic ointments.

Ocular examination revealed a painless mass, without proptosis or restriction of ocular movements. Visual acuity was 20/20-OD and 20/ 25-OS. Biomicroscopy and fundus examination were normal. Systemic investigation revealed a positive PPD test; she had a normal chest X-ray.

Computed tomography of the orbits indicated alterations of soft tissues (Fig. 3A), and an inferior trans-conjunctival biopsy was performed, revealing caseous necrosis, but with negative staining for

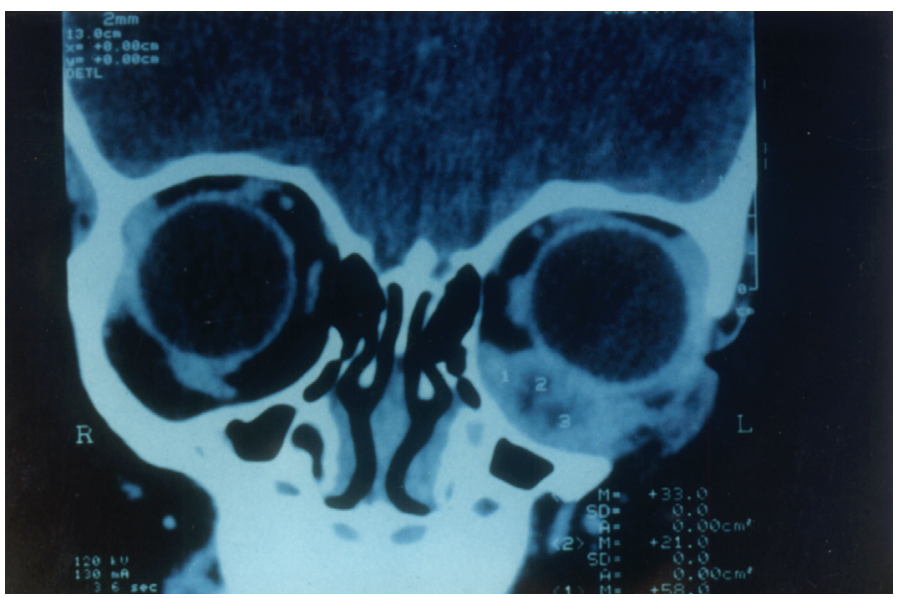

Fig. 3A - Case 3: CT - inferior left orbital mass. 
acid-fast bacilli. Immunohistochemical test was positive for $M$. tuberculosis (Fig. 3B). Specific anti-tuberculosis therapy was then employed (rifampin $15 \mathrm{mg} / \mathrm{kg}$ daily, isoniazid $10 \mathrm{mg} / \mathrm{kg}$ daily and pyrazinamide $30 \mathrm{mg} / \mathrm{kg}$ daily, for six months), with remission of the condition.

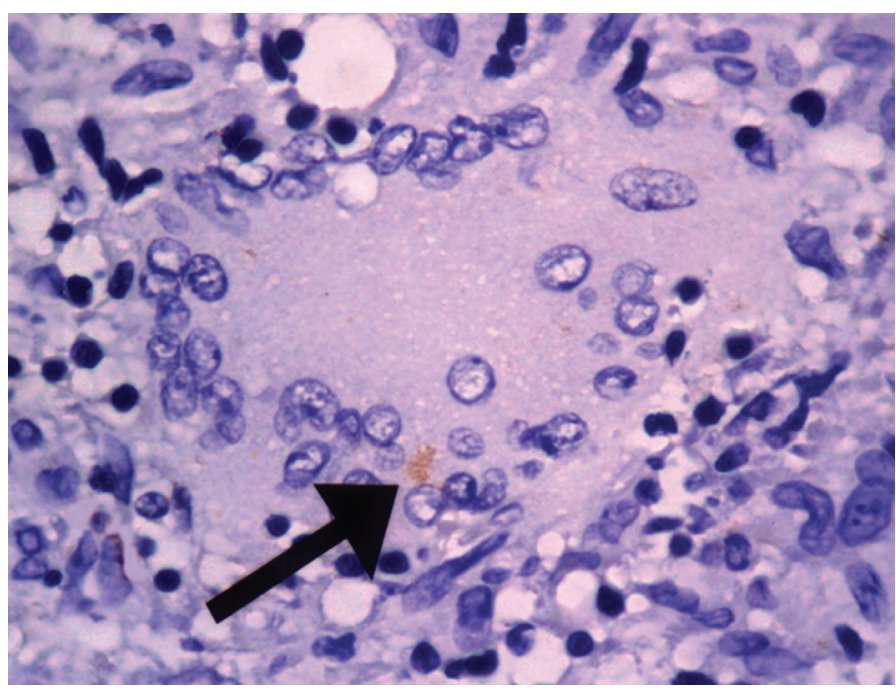

Fig. 3B - Case 3: Immunohistologic demonstration of Mycobacterium bovis (Bacillus Calmette-Guérin, BCG) within multinucleated giant cell (arrow) in a biopsy specimen of orbital granuloma (Immunoperoxidase staining with anti-Mycobacterium bovis and hematoxylin counterstain; original magnification, 1000x)

\section{DISCUSSION}

The world prevalence of tuberculosis is still high, mainly due to inadequate control in developing countries and to its association with HIV infection. There were an estimated eight to nine million new cases of tuberculosis in the world in 2000, of which three to four million were pulmonary sputum smear positive (most infectious form of the disease) ${ }^{1}$. Brazil is the only Latin American country considered to be among the 22 high-burden countries for tuberculosis in the world ${ }^{1}$, and in São Paulo state there was a total of 17969 new cases in 2002 (9097 pulmonary sputum smear positive) $)^{6}$.

Orbital involvement by tuberculosis, even in endemic areas, is rare res, $^{3,5}$. It can present as periostitis of orbital margin, tuberculoma of orbital tissues or tuberculoma of lacrimal gland ${ }^{2,4,5,7,8}$. Whereas periostitis is the most common form till the second decade of life, orbital tuberculoma is more frequent in middle-aged women ${ }^{2,4}$, without evidence of systemic disease ${ }^{3,4,5}$. Orbital infection can occur due to hematogenic spread as well as to direct spread from contiguous sites (paranasal sinuses, lacrimal gland and sac $)^{2,5,7,8}$

The most common clinical manifestations of orbital tuberculosis are insidious and progressive unilateral proptosis, a cold, painless eyelid swelling, chemosis and conjunctival hyperemia; in some cases there may be involvement of the ocular movements ${ }^{3,4,7}$ and, in few ones, loss of visual acuity or visual field ${ }^{3}$. Computed Tomography shows non-specific signs like proptosis and alterations in soft tissues, including orbital fat.

Culture of mycobacteria is considered the most sensitive method of detecting infections, although it may take weeks to months before organisms can be identified. On the other hand, identifying mycobacteria in tissue sections and smears is the most rapid way of detecting these infections. However, tissue detection of fast bacilli may be extremely difficult, and the Ziehl-Neelsen staining is negative many times, as occurred with the subjects in this study. In the first two cases, the noncaseous granulomatous reaction and the negative tissue staining did not help on the diagnosis, and only the immunohistochemical analysis could confirm it. The third case presented a more classical caseous granuloma, but with negative fast acid bacilli staining; immunohistochemical analysis was positive to $M$. tuberculosis too.

WILEY et al., $1990^{10}$, studied tissue sections of 34 cases of mycobacteria and concluded that immunohistochemistry with immunoperoxidase was more sensitive than common staining methods for detecting mycobacteria in tissue specimens. Moreover, it enables rapid identification of antigen, as it stains not only whole organisms, but also fragments and debris, detecting infection even in cases of caseous necrosis. As tuberculosis infection causes considerable morbidity and mortality in both the immunodeficient patient as well as the immunocompetent, it is extremely important to identify $M$. tuberculosis in tissue sections whenever possible. Note that all our three cases of orbital tuberculosis occurred in healthy patients with no HIV infection or any immunodeficiency.

Another test employed in tuberculosis research is PPD (purified protein derivative) test. However it is not a conclusive test because a positive PPD does not indicate active disease, only previous contact with the $M$. tuberculosis ${ }^{9}$. In these series, the systemic examination also did not help clinical diagnosis.

The differential diagnosis of orbital tuberculosis includes diseases that cause unilateral proptosis. In adults, one should consider pseudotumor of the orbit ${ }^{5}$, lymphoma, cavernous hemangioma, among others. In one of the cases, there was a misdiagnosed as pseudotumor of the orbit, which was treated with corticosteroids, with a good initial response. As the definitive diagnosis was tuberculosis, we believe that the good evolution in the beginning of the treatment with corticosteroids was due only to an inhibition of the inflammatory response.

In some cases, residual fibrosis or cicatricial ectropion can demand surgical procedures.

Involvement of the orbits is a rare manifestation of tuberculosis. Even in a tertiary hospital, few cases, if any, are diagnosed per year. However, the global incidence and prevalence of M. tuberculosis infections is not under control yet, and it has been a serious public health problem ${ }^{1}$. Thus, one must be aware of the possibility of tuberculosis among the orbital disease, when dealing with orbital mass/tumor.

\section{RESUMO}

\section{Tuberculose orbitária diagnosticada por imunohistoquímica}

Objetivo: Este estudo descreve 3 casos de tuberculose orbitária, com suas características clínicas, procedimentos diagnósticos, mostrando a importância da histopatologia para o diagnóstico correto. 
Pacientes e métodos: Descrição de 3 casos de pacientes com tuberculose orbitária diagnosticada e tratada no Hospital das Clínicas da Faculdade de Medicina da Universidade de São Paulo entre os anos 1999 e 2001

Resultados: Todos os casos apresentaram-se como massa orbitária de evolução lenta e progressiva em pacientes de sexo feminino, sem doença pulmonar concomitante evidente. Duas tinham epidemiologia positiva para tuberculose. A pesquisa de bacilo álcool ácido resistente (BAAR), pelo método de Ziehl-Neelsen, entretanto, havia sido negativa em todos os casos. O diagnóstico etiológico nos três pacientes foi realizado pela identificação imunohistoquímica de bacilos tuberculínicos intracitoplasmáticos.

Comentários: Baseando-se na elevada prevalência da tuberculose nos países em desenvovimento, associada ao aumento de sua incidência na última década, torna-se necessário considerá-la no diagnóstico diferencial das massas orbitárias em nosso meio.

\section{ACKNOWLEDGEMENT}

Dr. Alfred Van Baak by English revision.

\section{REFERENCES}

1. DAVIES, P.D.O. - The world-wide increase in tuberculosis: how demographic changes, HIV infection and increasing numbers in poverty are increasing tuberculosis. Ann. Med., 35: 235-243, 2003.
2. FRASSON, A.; OLIVEIRA, T.; MANSO, P. \& NEVES, R. - Tuberculosis of the lacrimal gland. Arq. bras. Oftal., 58: 369-370, 1995.

3. KHALIL, M.; LINDLEY, S. \& MATOUK, E. - Tuberculosis of the orbit. Ophthalmology, 92: 1624-1627, 1985

4. MORTADA, A. - Tuberculoma of the orbit and lacrimal gland. Brit. J. Ophthal., 55: 565-567, 1971.

5. PILlAI, S.; MALONE, T.J. \& ABAD, J.C. - Orbital tuberculosis. Ophthal. Plast. Reconstr. Surg., 11: 27-31, 1995.

6. SECRETARIA DE ESTADO DA SAÚDE DE SÃO PAULO/Centro de Vigilância Epidemiológica - Tuberculose. Accessed: http://www.cve.saude.sp.gov.br/htm/tb/ tb_cn02.htm

7. SEM, D. - Tuberculosis of the orbit and lacrimal gland: a clinical study of 14 cases. J. pediat. Ophthal. Strab., 17: 232-238, 1980.

8. SPOOR, T. \& HARDING, S.A. - Orbital tuberculosis. Amer. J. Ophthal., 91: 644-647, 1981.

9. TRABULSI, L.R.; ALTERTHUM, F.; GOMPERTZ, O.F. \& CANDEIAS, J.A.N. Bacteriologia médica. In: TRABULSI, L.R. Microbiologia. Rio de Janeiro, Atheneu, 1991, p, 191.

10. WILEY, E.L.; MULHOLLAN, T.J.; BECK, B.; TYNDALL, J.A. \& FREEMAN, R.G. Polyclonal antibodies raised against Bacillus Calmette-Guerrin, Mycobacterium duvalii, and Mycobacterium paratuberculosis used to detect mycobacteria in tissue with the use of immunohistochemical techniques. Amer. J. clin Path., 94: 307-312, 1990 .

Received: 18 March 2004

Accepted: 3 September 2004 